\title{
As Lições de um Desastre
}

A

reprovação de todos os candidatos que se apresentaram à primeira prova (eliminatória) de Administração Pública, no Concurso para provimento dos cargos iniciais da Carreira de Técnico de Administração - e foram apenas 41 dentre mais de 200 inscritos - não terá surpreendido aos observadores isentos da realidade administrativa federal. Neste mesmo local, em abril, chegamos a antecipar tal resultado. Na ocasião, alguns tacharam o nosso comentário de ferino e destituído de qualquer espírito construtivo; já outros apenas discerniram indícios de um melancólico pessimismo. Relendo agora aquêle Editorial, admitimos de bom grado o que os críticos haviam assinalado: talvez pouco oportuna, a ironia lá estava; mas não era verdade que o viciasse qualquer pessimismo, e menos ainda que nêle se encontrassem observações sem espírito construtivo.

Preocupavam-nos, sim, dois problemas: o assessoramento técnico dos homens públicos brasileiros - ainda agora à espera de solução - e o preenchimento eficiente das direções e chefias até hoje feito em bases subjetivas e de favor. Têm sido êles iratados com tal displicência ou desconhecimento de seus elementos essenciais, que se torna difícil formulá-los com objetividade. Resvala-se involuntàriamente para a facécia, dado o que ensina a experiência de anos recentes. Ou aceita-se resignado a penúria satisfeita em que se vem vegetando há tanto tempo. E' evidente, porém, que uma atitude desencantada ou sarcástica não ajuda a resolvêlos. Na verdade, ainda não se deram conta dêsses problemas os seus maiores interessados, isto é, a classe dirigente do país qure responde, afinal, pela falta de confiança generalizada que ainda inspira - a dar-se crédito ao que muitas vêzes se lê na Imprensa brasileira - a Administração Pública Federal. No entanto, a solução dêsses problemas já fôra encaminhada com fervoroso espírito público pelo Sr. LUIz Simões LOPES, há cêrca de vinte anos. 
Ninguém ignora, com efeito, os esforços de S. S. ${ }^{a}$ para dotar o nosso serviço público de um tipo de profissional semelhante ao que, $\mathrm{cm}$ diversos países da Europa, é o Inspetor de Finanças, ou nos Eistados Unidos, o Analista Administrativo. Ninguém ignora tampouco que sem uma classe administrativa de capacidade superior, que seja respeitada pela autoridade de suas idéias e realizações, não se poderá erradicar o mal da outorga de chefia como um ato de amizade e confiança. Causa estranheza, pois, que se tenha tergíversado tão nitidamente ante a experiência feita, descurando-se de renovar e enriquecer o núcleo de Técnicos de Administração inicialmente constituído, como se a reforma e a regeneração da administração pública federal pudessem, algum dia, ser levadas a efeito sem recorrer a êsse tipo de servidor.

Quem faz das ciências sociais aplicadas o trampolim de sua ação, e não transige nem pactua com as exigências de uma probidade intelectual e moral, que o estudo desinteressado sempre suscita e alimenta, é funcionário que pode honrar a qualquer administração. Mas um Técnico de Administração - tipo de homem e de profissional que só o tempo amadurece e apura - já o disseram figuras de responsabilidade como, por exemplo, o prof. Robert Hutchins, Presidente da Universidade de Chicago não se improvisa nem se inventa. Conviria amparar-1he o desenvolvimento; talvez mesmo - o que é mais ambicioso - criar condições gerais que permitissem o seu aparecimento. Só assim os empreendimentos públicos passariam a ser administrados com maior proficiência, perdendo o caráter de aventura ou tentativa a que muitas vêzes se reduzem.

Que lições conviria, então, retirar daquele desastre tão constrangedor, não sòmente para os centros de formação intelectual do país, senão também para o próprio serviço público federal, que não sabe - ou já não pode - atrair homens de cultura geral e especializada bastante sólida, a fim de organizar a equipe de estudiosos, que deverão auxiliar os nossos homens públicos, no planejamento e na execução de seus programas?

Parece-nos possivel distinguir diferentes lições com diferentes gostos naquela reprovação maciça. Umas são azêdas; outras, amargas; tôdas, porém, dignas de atenção, ainda que inaceitáveis a certos paladares. Vale a pena comentá-las, conforme o sabor que thes seja próprio. 
Registre-se, preliminarmente, a incapacidade revelada por quase todos os candidatos para apresentar, em têrmos inteligíveis e com boa organização, idéias ou informações gerais, mesmo quando se tratasse do que há de mais cediço na matéria. Redigiam mal e precàriamente porque pensavam ou haviam assimilado mal e precàriamente. Comprovou-se, portanto, o bordão clássico, como, em regra, aliás, sempre se comprova, quando há concurso ou prova de certa importância entre nós. Eis uma lição cuja acridez dificilmente se remediará, mas que os homens de responsabilidade do país precisam remediar.

Existe, sem dúvida, deficiência grave, que importa localizar para corrigir, em nossos cursos secundários, e particularmente no ensino da lingua nacional, porque êstes já não proporcionam como outrora, a possibilidade de aquisição de conhecimentos especiali-. zados ou de sua rigorosa veiculação. Ao contrário, os vícios intelectuais adquiridos na preparação atabalhoaa'a de tantas provas parciais e finais vão, a pouco e pouco, deformando a inteligência brasileira, e de tal modo que um concurso como o de Técnico de Administração se transforma apenas em mais outra demonstração - se acaso fôsse necessária - do psitacismo aparvalhado com que se decoram súmulas de aulas ou trechos de compêndios, scm a menor demonstração de trabalho intelectual próprio ou assimilação consciente da matéria.

Assinale-se, em seguida, outra lição azêda: a desilusão sofrida por tantos candidatos - sabe Deus por que motivos! - ao verificarem que não thes bastava o conhecimento de meia dúzia de noções, esquemas e classificações para que lhes pudesse ser conferido, automàticamente, o direito de se considerarem técnicos, pois é bem certo que, defrontados com um problema como o da Reforma Administrativa (tema proposto para Dissertação), logo se evidenciou em todos êles a incapacidade de aplicar aquelas parcas noções teóricas aos fatos administrativos porventura conhecidos, e que deviam constituir a matéria prima do estudo a fazer. Os nossos Cursos Superiores de Administração ainda não preenchem, portanto, as funções para que foram criados: não apercebem $Q$ estudante da exata atitude mental ante os problemas administrativos; ensinam quando muito a aplicar o lugar-comum de teoria administrativa ao caso ocorrente, sem indagar se the convém ou não. Em suma, tumultuam inteligências ao invés de as organizar e disciplinar; tal, pelo menos, foi o que se pôde verificar no concurso 
agora realizado. Retrucar-se-á que os diplomados por aquêles cursos, cônscios de seu valor e chamados a mais nobres e lucrativas tarefas, se desinteressaram pelo concurso de Técnico de Administração. Eis uma observação que, encerrando seu grão de verdade, nos leva a uma terceira lição — bem amarga lição.

A carreira de Técnico de Administração, no serviço público federa1, é uma carreira abastardada. Sua situação de eminência inicial, relativamente a outras, alterou-se de modo profundo e desastrado, sohretudo com o advento das Tabelas Únicas e o posterior malôgro do primeiro Plano de Classificação de Cargos. Não são convidativos, efetivamente, os padrões de remuneração da carreira, em manifesta desigualdade com séries funcionais assemelhadas, mas, na realidade, de níveis inferiores, quer quanto às qualiticações, quer quanto às responsabilidades. Nada mais natural que um cargo de classe $J(\mathrm{Cr} \$ 10.000,00)$ não possa atrair a quem dispõe de instrução universitária, para não falar em outros requisitos, indispensáveis e fundamentais. Será acaso essa remuneração um juro aceitável para tantos investimentos financeiros e morais? Será êsse o incentivo para quem deve passar pelo crivo de várias provas, inclusive a de preparar uma tese e defendê-la, a exemplo de IIm concurso para postos de ensino Universitário? Localiza-se, com estas observações elementares, o núcleo essencial do problema. A Administração Pública Federal, em virtude do alheamento teimoso que vem manifestando em relação às verdadeiras condições vigentes do mercado de trabalho técnico, já não consegue seduzir inteligências e culturas jovens; mais grave ainda: arrisca-se a perder os elementos já recrutados, desviados muitas vêzes pelos me1hores salários que as próprias autarquias e sociedades de economia mista oferecem em seus quadros funcionais.

Não espanta que o problema da chefia e da direção, no Serviço Público Federal, seja hoje a pedra no caminho de qualquer plano construtivo, que acaso se elabore para torná-1o mais eficiente, sobretudo no seu funcionamento. Existe uma crise de chefia porque existe uma errônea concepção do que ela comporta, exige ou pressupõe, e porque se tem descurado, acima de tudo, de recritar e de conservar o tipo de profissional superior sem o qual nenhuma organização alcança seus propósitos. 